\title{
The relationship of sperm viability and concentration to serum-induced head-to-head agglutination of bovine spermatozoa
}

\author{
E. P. Aalseth*, P. L. Senger and W. C. Becker \\ Department of Animal Sciences, Washington State University, Pullman, Washington 99164, U.S.A.
}

\begin{abstract}
Summary. Individual samples of bull semen were treated by filtration to remove immotile spermatozoa and by the addition of $10 \%$ heifer serum. There was significantly $(P<0.01)$ greater serum-induced agglutination in the filtered than in the unfiltered samples. Head-to-head agglutination was also greater $(P<0.01)$ in dilute sperm suspensions when compared to concentrated sperm suspensions.
\end{abstract}

\section{Introduction}

When heat-treated homologous female blood serum is added to diluted spermatozoa, head-to-head agglutination occurs but does not damage the spermatozoa of bulls (Senger \& Saacke, 1973, 1976; Saacke, O'Connor \& Chandler, 1976; O'Connor, Robbins, Vinson \& Saacke, 1974) or rams (Parks, Meacham \& Saacke, 1976).

Senger \& Saacke (1976) suggest that only spermatozoa with intact plasma and acrosomal membranes are capable of head-to-head agglutination but the causes of and cellular prerequisites for head-to-head agglutination of bovine spermatozoa have not been defined. Two factors which may be important to the incidence of head-to-head agglutination are the degree of sperm viability and the concentration of spermatozoa. With the aim of understanding better the factors which influence serum-induced head-to-head agglutination the current study was undertaken to: (1) determine the influence of sperm concentration on the degree of serum-induced head-to-head agglutination and (2) compare the degree of head-to-head agglutination among normal semen samples and those in which viability has been increased by removal of non-viable spermatozoa.

\section{Materials and Methods}

Split ejaculates from each of 6 bulls were pooled and diluted turbidimetrically in a yolk-Trisglycerol diluent (final diluent composition: $30 \cdot 28 \mathrm{~g}$ Tris hydroxymethyl amino methane $/ 1,12.50 \mathrm{~g}$ fructose $/ 1,17 \cdot 30 \mathrm{~g}$ citric acid monohydrate $/ 1,20 \%(\mathrm{v} / \mathrm{v})$ egg yolk and $8 \%(\mathrm{v} / \mathrm{v})$ glycerol) to give concentrations of $20,60,100$ or $140 \times 10^{6}$ spermatozoa $/ \mathrm{ml}$. The semen was packaged in $0.5-\mathrm{ml}$ French straws, frozen in liquid $\mathrm{N}_{2}$ vapour and stored in liquid nitrogen. Semen was thawed at $35^{\circ} \mathrm{C}$ for $1 \mathrm{~min}$ and maintained at $37^{\circ} \mathrm{C}$ throughout the experiment.

Immediately after thawing, half of the samples at each concentration were filtered (Treatment F) and the rest unfiltered (Treatment $\mathrm{C}$ ). The filtration was to remove immotile spermatozoa so that the sample contained predominantly motile spermatozoa with intact acrosomal membranes. Filtration was accomplished by a modification of the technique of Graham, Schmehl \& Maki-Laurila (1970). A peristaltic pump (Gilson Minipuls II 4 channel Model HP4) was used to move $1.5 \mathrm{ml}$ semen through $10 \mathrm{mg}$ glass wool (0.725-1.596 $\mu \mathrm{m}$ fibre diam., Johns-Manneville) which was packed gently in a $3-\mathrm{ml}$ plastic syringe barrel attached to the peristaltic pump with polyvinylchloride tubing. The filtration process required a total of $30 \mathrm{~min}$ at a rate of approximately $50 \mu \mathrm{l} / \mathrm{min}$. All unfiltered samples were incubated at $37^{\circ} \mathrm{C}$ for the same period of time.

* Present address: Department of Dairy Science, Virginia Polytechnic Institute and State University, Blacksburg, Virginia 24061, U.S.A. 
Spermatozoa in half of the filtered and unfiltered samples were agglutinated by adding serum $(10 \% \mathrm{v} / \mathrm{v})$ (Senger \& Saacke, 1976). The serum was obtained from 10 virgin heifers, pooled and heated at $56^{\circ} \mathrm{C}$ for $30 \mathrm{~min}$ to destroy spermicidal factors (Chang, 1947). All the samples with serum (Treatments Fs and Cs) and without serum (Treatments $\mathrm{Fc}$ and $\mathrm{Cc}$ ) were incubated at $37^{\circ} \mathrm{C}$ for $30 \mathrm{~min}$.

Evaluation of the percentages of intact acrosomes (Saacke \& White, 1972), head-to-head agglutination (Senger \& Saacke, 1976) and motility were made at 1,4 and $7 \mathrm{~h}$ after thawing by examination of unfixed smears with differential interference-contrast $(\times 800)$ and phase-contrast $(\times 128)$ microscopy. Direct haemocytometer sperm counts were made on all samples before the treatments to determine the loss of spermatozoa due to filtration and the actual sperm concentrations in the unfiltered samples.

Treatments Fc (filtered non-agglutinated) and Cc (unfiltered non-agglutinated) served as controls for Treatments Fs (filtered agglutinated) and Cs (unfiltered agglutinated). Duplicate observations were conducted on each sample and all samples were coded to avoid observer bias.

The data were assessed by analyses of variance with the main effects being bulls (6), sperm concentrations $\left(20,60,100\right.$ or $\left.140 \times 10^{6} / \mathrm{ml}\right)$, treatments (Fs, Fc, Cs and $\mathrm{Cc}$ ) and time of incubation $(1,4$ or $7 \mathrm{~h})$. All possible two-way interactions were included in the analyses.

\section{Results}

The actual sperm concentrations in the unfiltered and filtered semen samples were $13.3-158 \times 10^{6}$ and $4 \cdot 5-75.8 \times 10^{6}$ spermatozoa $/ \mathrm{ml}$ respectively, and for both treatments there was a significant negative correlation ( $r=-0.86$ for Cs; $r=-0.78$ for Fs) between the sperm concentration and the percentage agglutination (Text-fig. 1). The effect of filtration on sperm concentration is shown in Table 1: the mean decrease after filtration was $55.9 \%$ (s.d. 8.9). There was a greater percentage of motility, acrosomal maintenance and agglutination in the filtered than in the unfiltered samples, regardless of the sperm concentration (Table 2, Text-fig. 1). The addition of heat-treated serum and the resulting agglutination did not improve motility or acrosomal maintenance for any of the samples (Table 2).

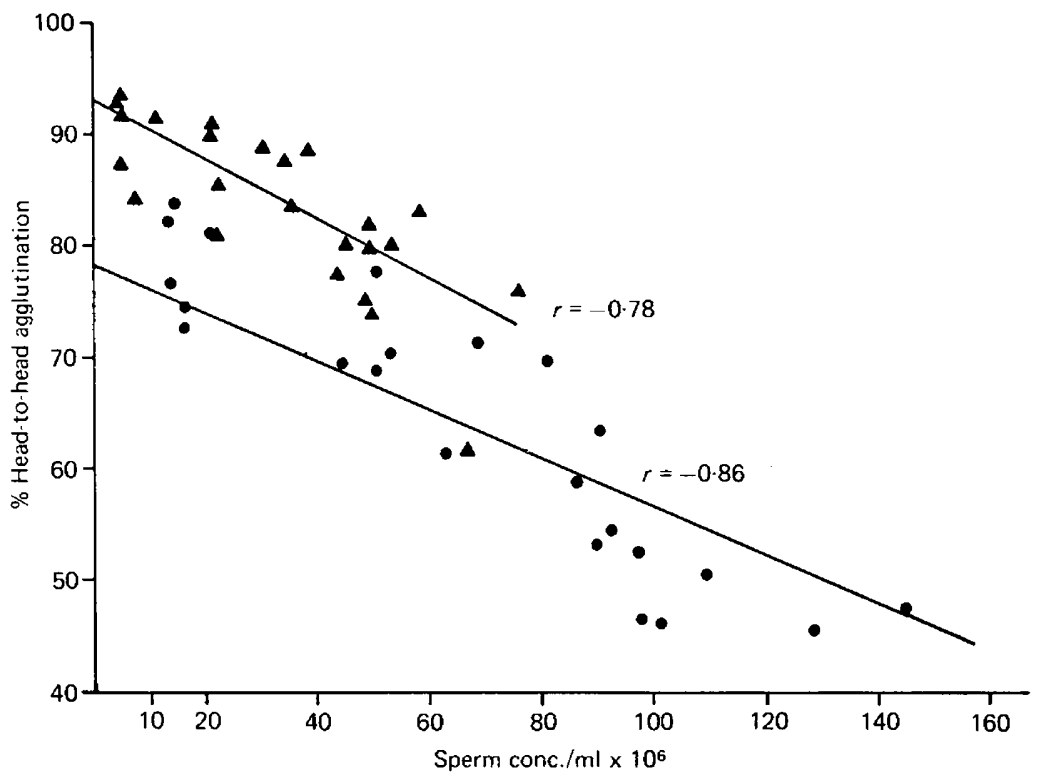

Text-fig. 1. The relationship of sperm concentration (measured directly with haemocytometer counts) to head-to-head agglutination in samples of filtered $(\boldsymbol{\Delta})$ and unfiltered $(\boldsymbol{\theta})$ bovine semen. Each point is the mean of duplicates for each bull. 
Table 1. Effect (mean \pm s.d. for 24 observations) of filtration on the sperm concentration of bovine semen

\begin{tabular}{|c|c|c|c|}
\hline \multirow[b]{2}{*}{ Desired conc. $\times 10^{6} / \mathrm{ml}$} & \multicolumn{2}{|c|}{ Actual sperm conc. $\times 10^{6} / \mathrm{ml}$} & \multirow[b]{2}{*}{$\%$ Decrease in conc. } \\
\hline & Before filtration & After filtration & \\
\hline 20 & $16 \cdot 8 \pm 4 \cdot 1$ & $6 \cdot 4 \pm 2 \cdot 3$ & $62 \cdot 4 \pm 8 \cdot 2$ \\
\hline 60 & $53.3 \pm 7.9$ & $25 \cdot 6 \pm 7 \cdot 1$ & $52.4 \pm 10.6$ \\
\hline 100 & $92.4 \pm 15 \cdot 4$ & $41.9 \pm 9.9$ & $54 \cdot 3 \pm 2 \cdot 4$ \\
\hline 140 & $129 \cdot 6 \pm 22.6$ & $59 \cdot 7 \pm 12 \cdot 4$ & $54 \cdot 5 \pm 6 \cdot 3$ \\
\hline
\end{tabular}

Table 2. Effect of sperm concentration, filtration and addition of blood serum on the motility, acrosomal integrity and head-to-head agglutination of bovine spermatozoa (means of 6 bulls and duplicates at 1,4 and $7 \mathrm{~h}$ of incubation)

\begin{tabular}{|c|c|c|c|c|c|c|c|}
\hline \multirow{3}{*}{$\begin{array}{l}\text { Sperm } \\
\text { conc. before } \\
\text { filtration } \\
\times 10^{6} / \mathrm{ml}\end{array}$} & \multirow{2}{*}{\multicolumn{2}{|c|}{ Treatment }} & \multirow{3}{*}{$\begin{array}{l}\text { Motility } \\
(\%)\end{array}$} & \multirow{3}{*}{$\begin{array}{c}\text { Intact } \\
\text { acrosomes } \\
(\%)\end{array}$} & \multirow{3}{*}{$\begin{array}{c}\text { Agglutination } \\
(\%)\end{array}$} & \multicolumn{2}{|c|}{$\begin{array}{l}\text { Correlation coefficients } \\
\text { with agglutination }\end{array}$} \\
\hline & & & & & & & \\
\hline & Filtration & Serum & & & & Motility & acrosomes \\
\hline 20 & + & + & $80 \cdot 4^{\mathrm{a}}$ & $89 \cdot 7^{a}$ & $91 \cdot 1^{a}$ & 0.77 & 0.88 \\
\hline 20 & + & - & $72 \cdot 9^{\mathrm{b}}$ & $88 \cdot 4^{\mathrm{a}}$ & & & \\
\hline 20 & - & + & $50 \cdot 1^{d}$ & $74 \cdot 8^{b}$ & $78 \cdot 3^{b}$ & & \\
\hline 20 & - & - & $60 \cdot 8^{c}$ & $76 \cdot 7^{\mathrm{b}}$ & & & \\
\hline 60 & + & + & $76 \cdot 4^{a}$ & $87 \cdot 4^{a}$ & $88 \cdot 0^{2}$ & 0.60 & 0.84 \\
\hline 60 & + & - & $78 \cdot 8^{\mathrm{a}}$ & $87 \cdot 0^{\mathrm{a}}$ & & & \\
\hline 60 & - & + & $58 \cdot 5^{\mathrm{b}}$ & $73 \cdot 5^{b}$ & $69.9^{\mathrm{b}}$ & & \\
\hline 60 & - & - & $59 \cdot 2^{\mathrm{b}}$ & $72 \cdot 8^{b}$ & & & \\
\hline 100 & + & + & $79 \cdot 3^{\mathrm{a}}$ & $86 \cdot 8^{a}$ & $82 \cdot 2^{\mathrm{a}}$ & 0.63 & 0.80 \\
\hline 100 & + & - & $77 \cdot 6^{\mathbf{a}}$ & $87 \cdot 7^{\mathrm{a}}$ & & & \\
\hline 100 & - & + & $60 \cdot 4^{b}$ & $72 \cdot 9^{b}$ & $58 \cdot 5^{\mathrm{b}}$ & & \\
\hline 100 & - & - & $63.8^{b}$ & $75 \cdot 5^{b}$ & & & \\
\hline 140 & + & + & $75 \cdot 7^{\mathrm{a}}$ & $86 \cdot 9^{\mathrm{a}}$ & $76 \cdot 5^{\mathrm{a}}$ & 0.52 & 0.69 \\
\hline 140 & + & - & $74 \cdot 0^{\mathrm{a}}$ & $85 \cdot 5^{2}$ & & & \\
\hline 140 & - & + & $62 \cdot 2^{b}$ & $71 \cdot 6^{b}$ & $48 \cdot 8^{b}$ & & \\
\hline 140 & - & - & $61 \cdot 4^{\mathrm{b}}$ & $73 \cdot 6^{b}$ & & & \\
\hline
\end{tabular}

Means with different superscripts within the same column and sperm concentration are significantly different $(P<0.01)$.

* These are derived from pooled values for the filtration + serum and the nonfiltration + serum treatments: all are significant at $P<0.01$.

\section{Discussion}

This study demonstrates that increasing sperm concentrations resulted in a reduced incidence of head-to-head agglutination of bovine spermatozoa. An equal volume of homologous serum was added to all samples, and therefore the quantity of serum per cell decreased as sperm concentration increased. Similar results have been reported for bovine spermatozoa by Saacke et al. (1976). These findings suggest that the serum factor(s) responsible for inducing agglutination become limited as sperm concentration increases and that spermatozoa are competing for them. The nature of this competition requires investigation.

Senger \& Saacke (1976) suggested that serum-induced head-to-head agglutination is selective in nature because relatively few agglutinated spermatozoa had damaged acrosomal membranes and acrosomal ageing of agglutinated spermatozoa was very slow during the 9-h incubation 
period. However, the fact that agglutination declined significantly during that incubation suggested that ageing does occur. A similar observation made in the present study also supports the concept that head-to-head agglutination primarily involves spermatozoa with intact acrosomal membranes because when the percentage of spermatozoa with intact acrosomes was increased by filtration (Table 2) the incidence of head-to-head agglutination was also increased. A comparison of filtered and unfiltered semen samples with similar sperm concentrations (Text-fig. 1) demonstrates that samples with higher semen quality due to filtration had a higher incidence of head-to-head agglutination.

A positive correlation between the percentage head-to-head agglutination and intact acrosomes was found by Senger \& Saacke (1973), and this was confirmed in the present study within each sperm concentration studied. The decline in the correlation coefficient with increasing concentrations was due to the decreasing incidence of percentage agglutination with the increased sperm concentrations. At the higher concentrations greater numbers of non-agglutinated spermatozoa with intact acrosomes were present.

Scientific paper No. 4827, College of Agriculture Research Center, Washington State University. This project (No. 4237) was funded in part by the National Association of Animal Breeders, Box 1033, Columbia, Missouri 65201, U.S.A. We thank Curtiss Breeding Service for providing the semen used in this study.

\section{References}

Chang, M.C. (1947) The effects of serum on spermatozoa. J. gen. Physiol. 30, 321-335.

Graham, E.F., Schmehl, M.K.L. \& Maki-Laurila, M. (1970) Some physical and chemical methods of evaluating semen. Proc. 3rd Tech. Conf., Anim. Reprod. \& A.I., pp. 44-48. National Association of Animal Breeders, Box 1033, Columbia, Mo., U.S.A.

O'CONNOR, M.L., ROBBINs, R.K., Vinson, W.E. \& SAACKE, R.G. (1974) Response of sperm to anti-yolk diluent sera. J. Anim. Sci. 39, 220, Abstr.

Parks, J.E., Meacham, T.N. \& SaAcke, R.G. (1976) Effects of serum on cold shocked ram spermatozoa. J. Anim. Sci. 42, 264, Abstr.

SAACKe, R.G. \& White, J.M. (1972) Semen quality tests and their relationship to fertility. Proc. 4th
Tech. Conf., Anim. Reprod. \& A.I., pp. 22-27. National Association of Animal Breeders, Box 1033, Columbia, Mo., U.S.A.

SaAcke, R.G., O'Connor, M.L. \& Chandler, J.E. (1976) Sperm concentration, the acrosome and agglutination. J. Anim. Sci. 43, 302, Abstr.

Senger, P.L. \& SaAcke, R.G. (1973) Effects of blood serum on bovine spermatozoa. J. Anim. Sci. 37, 328, Abstr.

SENGER, P.L. \& SAACKe, R.G. (1976) Serum-induced head-to-head agglutination of bovine spermatozoa. J. Reprod. Fert. 47, 215-219. 